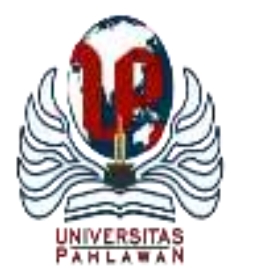

Edukatif : Jurnal Ilmu Pendidikan Volume 3 Nomor 5 Tahun 2021 Halm 3204 - 3214

EDUKATIF: JURNAL ILMU PENDIDIKAN

Research \& Learning in Education

https:/ledukatif.org/index.php/edukatif/index

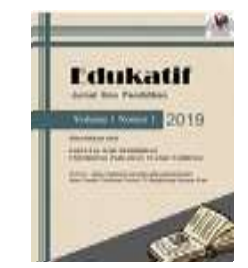

\title{
Budaya Matriarki dalam Pementasan Monolog "Racun Tembakau" Karya Anton Chekov oleh Teater Gabung Unsika (Kajian Semiotika Charles S. Pierce)
}

\author{
Intan Fajri Mulyaningsih ${ }^{1 凶}$, Uah Maspuroh $^{2}$, Sinta Rosalina $^{3}$ \\ Universitas Singaperbangsa Karawang, Indonesia ${ }^{1,2,3}$

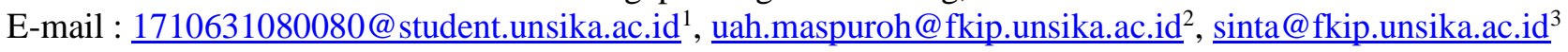

\begin{abstract}
Abstrak
Penelitian ini membahas bagaimana proses penciptaan makna dalam sebuah pementasan teater. Dalam pementasan teater sering kali ditemukan banyak makna yang tentu saja menimbulkan lebih dari satu arti yang berbeda pada masing-masing penonton. Maka dari itu, penelitian ini bertujuan untuk mengungkap bagaimana makna yang hadir dalam pementasan teater "Racun Tembakau" karya Anton Chekov yang dimainkan oleh seniman Teater Gabung Unsika. Pun, peneliti ingin mengetahui bagaimana aktor dan sutradara sebuah pementasan teater membangun dan menciptakan tanda-tanda yang menunjukkan adanya budaya matriarki dalam pementasan "Racun Tembakau" tersebut. Penelitian dilakukan dengan metode penelitian yang bersifat kualitatif, yang mana peneliti melakukan pendeskripsian atas elemen-elemen yang terkait dalam berjalannya penelitian. Metode deskripsi dilakukan mulai dari proses pengumpulan data, reduksi data, penyajian data, sampai dengan yang terakhir yaitu membuat kesimpulan. Dalam mengkaji penelitian ini, peneliti menggunakan teori semiotika dari Charles S. Pierce sebagai acuan dalam menganalisis data-data yang sudah terkumpul. Isi penelitian ini merupakan hasil pendeskripsian peneliti dengan berlandaskan teori yang digunakan. Hasil yang didapat dari penelitian ini mengungkap adanya budaya matriarki dalam pementasan tersebut.
\end{abstract}

Kata Kunci: semiotika, teater, budaya matriarki.

\begin{abstract}
This study discusses the process of creating meaning in a theatrical performance. In theatrical performances, many meanings are often found, which of course gives rise to more than one different meaning for each audience. Therefore, this study aims to reveal how the meaning is present in the theatrical performance of "Tobacco Poison" by Anton Chekov, which is played by Gabung's Theater of Unsika. Also, the researcher wants to know how actors and directors of a theater performance build and create signs that indicate the existence of a matriarchal culture in the performance of "Tobacco Poison". The research was conducted using a qualitative research method, in which the researcher described the elements involved in the course of the research. The description method is carried out starting from the process of data collection, data reduction, data presentation, until the last one is making conclusions. In reviewing this research, the researcher uses the semiotic theory of Charles S. Pierce as a reference in analyzing the data that has been collected. The content of this research is the result of the researcher's description based on the theory used. The results obtained from this study reveal the existence of a matriarchal culture in the performance.
\end{abstract}

Keywords: semiotics, theater, matriarchal culture

Copyright (c) 2021 Intan Fajri Mulyaningsih, Uah Maspuroh, Sinta Rosalina

$\triangle$ Corresponding author

Email : $1710631080080 @$ student.unsika.ac.id

DOI : https://doi.org/10.31004/edukatif.v3i5.1257

ISSN 2656-8063 (Media Cetak)

ISSN 2656-8071 (Media Online) 
3205 Budaya Matriarki dalam Pementasan Monolog "Racun Tembakau” Karya Anton Chekov oleh Teater Gabung Unsika (Kajian Semiotika Charles S. Pierce)-Intan Fajri Mulyaningsih, Uah Maspuroh, Sinta Rosalina

DOI: https://doi.org/10.31004/edukatif.v3i5.1257

\section{PENDAHULUAN}

Secara epistemologi, istilah semiotika berasal dari bahasa Yunani "Semion" yang memiliki arti tanda. Semiotika merupakan suatu ilmu yang mempelajari segala hal tentang tanda dan pemaknaannya. Pierce (dalam Zaimar, 2014:2) menyatakan bahwa tanda dapat didefinisikan sebagai sesuatu yang dapat mewakili suatu entitas dan yang lainnya sesuai dengan kodratnya. Dengan begitu, dapat ditarik kesimpulan bahwa semiotika merupakan ilmu yang mempelajari suatu tanda atau lambang. Definisi tersebut muncul dengan alasan bahwa semiotik selalu membahas segala sesuatu yang berkaitan dengan tanda, antara lain macammacam tanda, proses penciptaan tanda, penggunaan tanda serta proses pemaknaan tanda.

Charles Sanders Pierce mengemukakan bahwa "a relationship among sign, an object a meaning" suatu hubungan di antara tanda, objek, dan makna. Tanda juga memiliki arti sebagai sesuatu yang sudah tergabung sebelumnya atas dasar konvensi sosial sehingga dapat dianggap mewakili sesuatu yang lain. Alex Sobur, dalam bukunya yang berjudul "Semiotika Komunikasi" mengatakan bahwa semiotika adalah suatu ilmu atau metode analisis yang digunakan untuk mengkaji tanda-tanda. Di samping itu, tanda-tanda merupakan perangkat atau alat yang biasa dipakai sebagai upaya seseorang dalam mencari jalan di dunia yang luasnya tak terjangkau ini bersama-sama manusia dan di tengah-tengah manusia.

Menurut Ferdinand Bruneterre, drama adalah salah satu karya sastra atau karya seni yang dapat melahirkan sebuah kehendak dari suatu action atau gerak yang dimainkan oleh pelaku. Tidak sedikit yang berasumsi bahwa drama tidak lebih dari sekadar tontonan. Sekilas tidak ada yang salah dari asumsi tersebut, sebuah drama memang dipentaskan untuk dipertontonkan oleh orang lain, tetapi drama juga tidak hanya sekadar untuk ditonton. Dalam hal ini, penonton memiliki peran penting dalam berhasilnya sebuah pertunjukan drama, apakah sebuah drama bisa dikatakan menarik atau tidak. Berbicara menarik atau tidaknya sebuah drama tentu berbeda-beda bagi masing-masing penonton dengan alasan setiap orang memiliki tafsiran tersendiri ketika menyaksikan sebuah drama. Seorang seniman drama dikenal cermat membaca kehidupan sekitarnya yang kemudian ditafsirkan dan diolah menjadi sebuah naskah atau teks. Naskah tersebut kemudian ditafsirkan lagi oleh sutradara agar menciptakan garapan yang lebih menarik. Tak jarang pula aktor atau pelaku drama tersebut menafsirkan kembali arahan dari sutradara yang kemudian memunculkan tafsiran yang berbeda dari masing-masing penonton. Maka dari itu, drama selalu multitafsir, yaitu menghadirkan berlapislapis tafsir yang tidak memiliki ujung. Terdapat banyak sekali simbol dalam sebuah pementasan drama, simbol tersebut dapat berupa metafor, alegori, dan personifikasi kehidupan sosial. Bahkan drama yang sifatnya absurd pun tetap terdapat sebuah simbol yang bermakna di dalamnya, tak hanya sekadar fantasi belaka.

Semiotik pertunjukan dalam pementasan drama adalah bagian dari kajian semiotika teater (pertunjukan panggung) yang berkaitan dengan teori tanda dan sistem tanda yang terdapat dalam sebuah seni pertunjukan atau teater. Semiotika teater mempelajari apa-apa yang menjadi komponen-komponen dalam teater dan menyimpulkan bahwa segala yang terdapat dalam kerangka teater merupakan tanda atau sign. Maka bisa diartikan bahwa pertunjukan teater merupakan sekumpulan sistem tanda. Tak sedikit pula yang berpendapat bahwa objek-objek yang ada di panggung memiliki arti yang bisa dikatakan lebih penting dalam kehidupan sehari-hari. Argumen yang melatarbelakangi pendapat tersebut adalah segala sesuatu seperti tanda-tanda teater yang menimbulkan berbagai macam karakteristik, sifat, serta atribut yang terdapat di atas panggung tetapi tidak dimiliki dalam kehidupan yang sebenarnya.

Semiotika dalam teater juga menganalisis bahasa-bahasa panggung yang mencakup gambar, fisik, auditif dalam teater dengan tujuan untuk menetapkan makna. Sedang di dalam film, semiotika telah melalui proses adopsi secara luas berupa mata kamera dalam menuntun pemaknaan. Mata kamera kemudian menyeleksi objek yang akan ditonton sehingga tanpa sadar penonton sudah berhasil memproses suatu 
penciptaan makna. Berbeda dengan film, teater tidak menggunakan kamera agar dapat ditonton. Segala komponen yang dibutuhkan dalam teater dibentangkan di atas panggung, sehingga panorama panggung dapat terlihat secara utuh oleh penonton. Maka dari itu, tanda-tanda yang tersebar di atas panggung itu harus dihierarki sedemikian rupa guna membantu penetapan makna.

Maksud dari penelitian ini yaitu mengkaji secara lebih dalam mengenai sistem tanda dan penginterpretasiannya dalam sebuah pertujukan drama. Dalam penelitian ini, penulis memilih pertunjukan drama berjudul "Racun Tembakau" karya Anton Chekov yang dimainkan oleh mahasiswa Universitas Singaperbangsa Karawang yang tergabung dalam Unit Kegiatan Mahasiswa (UKM) Teater Gabung. Pertunjukan tersebut dipilih penulis dengan alasan bahwa penulis ingin mengetahui bagaimana proses penciptaan dan penyajian seni pertunjukan drama yang dilakukan oleh mahasiswa. Selain itu, penulis juga ingin mengetahui sistem tanda yang diciptakan oleh mahasiswa melalui seni pertunjukan drama tersebut.

Penelitian ini tentu memberikan manfaat secara langsung maupun tidak langsung dalam dunia pendidikan khususnya. Hasil dari penelitian ini bisa digunakan sebagai pedoman mahasiswa Program Studi Pendidikan Bahasa dan Sastra Indonesia dalam mengkaji atau menganalisis sebuah seni pertunjukan teater/drama. Tidak sedikit penonton pertunjukan teater yang salah tafsir akan pesan atau makna dari tandatanda yang diciptakan dari sebuah pertunjukan drama/teater. Maka dari itu, penelitian ini dapat membantu dalam meluruskan salah tafsir yang seringkali terjadi pada sebuah pertunjukan drama/teater. Hal tersebut juga menjadi alasan penulis melakukan penelitian ini.

Penelitian ini memiliki persamaan dengan penelitian yang dilakukan oleh Petrus Poerwadi dan Misnawati dengan judul "Kajian Semiotik Pertunjukan dalam Performa Drama "Balada Sakit Jiwa" yaitu sama-sama mengkaji tentang tanda-tanda yang terdapat dalam sebuah seni pertunjukan drama. Meskipun terdapat beberapa kesamaan dengan penelitian terdahulu, namun tidak sedikit pula perbedaan yang terdapat antara penelitian ini dan penelitian sebelumnya, mulai dari objek yang digunakan sampai dengan metode penelitiannya. Penelitian sebelumnya mengkaji drama dengan banyak aktor, sedangkan penelitian ini mengkaji drama yang hanya terdapat satu aktor dalam satu pertunjukan atau biasa disebut monolog. Selain itu, penelitian tersebut mendeskripsikan interpretasi makna dari keseluruhan tanda yang terdapat dalam pertunjukan. Sedang penelitian ini memfokuskan pada bagaimana tanda yang diciptakan dan interpretasi akan makna tanda yang menunjukkan adanya budaya matriarki saja, tidak keseluruhannya. Penelitian yang dilakukan Petrus Poerwadi dan Misnawati menggunakan metode pengamatan langsung mulai dari awal latihan sampai dengan drama dipentaskan. Berbeda dengan penelitian ini, yang mana hanya melakukan pengamatan melalui video pertunjukan yang sudah diunggah ke YouTube.

Rumusan masalah yang ingin diteliti dalam penelitian ini adalah bagaimana makna dan pembentukan makna yang terkandung dalam pementasan monolog "Racun Tembakau" yang dimainkan oleh Teater Gabung Unsika sehingga menciptakan kesan adanya budaya matriarki. Penelitian ini dirasa penting dan harus segera dilakukan dengan tujuan untuk meluruskan salah tafsir atau kesalahpahaman penonton setelah menyaksikan pertunjukan drama/teater yang telah ditonton. Dari apa yang yang telah dipaparkan di atas, maka penulis ingin melakukan penelitian dengan judul "Budaya Matriarki dalam Pementasan Monolog "Racun Tembakau" karya Anton Chekov oleh Teater Gabung Unsika (Kajian Semiotika Charles S. Pierce)”.

\section{METODE PENELITIAN}

Dalam menyusun penelitian ini, penulis menggunakan pendekatan kualitatif. Sugiyono (2016:9) mengatakan bahwa penelitian kualitatif adalah penelitian yang mana si peneliti dijadikan sebagai instrumen kunci atau utama. Maksudnya, penelitian kualitatif adalah penelitian yang bersifat alamiah dari peneliti dalam mengkaji suatu objek. Penelitian kualitatif membuahkan hasil berupa penemuan-penemuan yang sudah pasti 
tidak dapat dicapai jika menggunakan prosedur statistik atau cara yang digunakan dalam penelitian kuantitatif. Penelitian kualitatif biasanya meneliti hal-hal yang berkaitan dengan kehidupan masyarakat, sejarah, tingkah laku, fungsionalisme organisasi, pergerakan sosial, juga hubungan kekerabatan. Dengan demikian, pendekatan yang digunakan dalam penelitian ini yaitu pendekatan kualitatif. Pendekatan kualitatif sendiri memiliki arti pendekatan yang digunakan untuk memperoleh data yang lebih mendalam, mengembangkan teori, serta untuk mendeskripsikan secara detail permasalahan yang diteliti. Maka dari itu, metode yang digunakan juga metode kualitatif. Metode kualitatif itu antara lain dengan melakukan wawancara dengan sumber informasi (dalam hal ini sutradara dan aktor yang terkait dalam pementasan), selain itu peneliti juga melakukan pengamatan terhadap video pementasan drama berjudul "Racun Tembakau" yang dimainkan oleh Teater Gabung Unsika.

Peneliti mengumpulkan data berdasarkan observasi yang dilakukan apa adanya dan tanpa ada faktor kesengajaan di dalamnya. Data yang diperlukan dalam penelitian ini adalah video pementasan drama "Racun Tembakau". Video tersebut diambil dari YouTube, maka teknik pengumpulan data yang digunakan dalam penelitian ini adalah dengan melakukan observasi terhadap video pementasan di YouTube, serta pencatatan data-data yang didapat dari wawancara yang telah dilakukan. Dengan menggunakan alasan situasi dan kondisi yang sedang terjadi di hampir seluruh dunia, termasuk Indonesia, maka peneliti melakukan pengumpulan data secara daring (dalam jaringan), mulai dari menonton video pementasan yang sudah diunggah ke Youtube, mencatat dan mengambil potongan-potongan gambar berisi adegan-adegan serta monolog yang mengandung makna, kemudian mewawancarai aktor juga sutradara terkait. Subjek dalam penelitian ini adalah video pertunjukan seni teater/drama berjudul "Racun Tembakau" karya Anton Chekov yang diinisiasi oleh mahasiswa Universitas Singaperbangsa Karawang yang tergabung dalam Unit Kegiatan Mahasiswa (UKM) Teater Gabung. Video tersebut didapat dari Youtube dan berdurasi sembilan belas lebih empat puluh enam menit. Sedangkan yang dijadikan objek dari penelitian ini adalah semiotika yang dihadirkan dalam setiap adegan di pementasan drama monolog "Racun Tembakau".

Dalam penelitian kualitatif, instrument penelitian yang utama adalah peneliti itu sendiri. Instrumen utama dalam penelitian ini yaitu penulis yang dalam hal ini berperan sebagai pengumpul data. Selain penulis, instrumen lain yang mendukung penelitian ini meliputi pedoman observasi dalam pengamatan video pementasan drama "Racun Tembakau" berupa potongan-potongan gambar yang memunculkan tanda, serta pedoman wawancara yang ditujukan untuk aktor dan sutradara pementasan. Analisis data dapat dilakukan ketika data-data yang dibutuhkan sudah terkumpul. Berangkat dari data yang sudah terkumpul kemudian nantinya akan dianalisis secara bertahap, mulai dari identifikasi data yang memiliki keterkaitan erat dengan rumusan masalah dalam penelitian ini. Dari data yang sudah diindentifikasi kemudian dianalisis dengan menggunakan teori semiotika teater, dan terakhir membuat kesimpulan dari data-data yang sudah dianalisis. Analisis data dimulai dengan melakukan telaah seluruh data yang diperoleh dari berbagai sumber, antara lain dari hasil wawancara, dokumen pribadi yang dimiliki, dan gambar foto atau potongan-potongan video pementasan dari Youtube. Dari sekian banyak data yang sudah berhasil terkumpul, makadilakukan telaah lebih dalam dan teliti. Selanjutnya melakukan reduksi data dengan cara abstraksi. Absraksi sendiri merupakan rangkuman yang dibuat memuat hal inti, proses, sampai dengan pernyataan-pernyataan yang bersifat penting. Setelah itu, menyusun abstraksi tersebut menjadi satuan-satuan yang kemudian dibuat menjadi kategori. Tahap akhir dari analisis data ini adalah dengan memeriksa keabsahan data. Selanjutnya, masuk pada tahap penafsiran data dengan metode-metode tertentu. 
3208 Budaya Matriarki dalam Pementasan Monolog "Racun Tembakau” Karya Anton Chekov oleh Teater Gabung Unsika (Kajian Semiotika Charles S. Pierce)-Intan Fajri Mulyaningsih, Uah Maspuroh, Sinta Rosalina

DOI: https://doi.org/10.31004/edukatif.v3i5.1257

\section{HASIL DAN PEMBAHASAN PENELITIAN}

\section{Deskripsi Objek Penelitian}

Monolog "Racun Tembakau" adalah salah satu naskah drama karya Anton Chekov yang sudah sering digarap oleh seniman-seniman hebat di Indonesia. Monolog ini mengangkat kisah seorang pria lanjut usia yang bekerja sebagai penceramah dan sering kali tertindas dengan sang istri. Monolog "Racun Tembakau" karya Anton Chekov ini merupakan hasil terjemahan Jim Adhi Limas dari naskah aslinya "On the Harmful Effects of Tobacco". Monolog ini sering digarap oleh seniman hebat seperti Rachman Sabur yang saat ini berstatus sebagai dosen seni peran di Fakultas Seni Pertunjukan (ISBI Bandung).

Teater Gabung adalah salah satu Unit Kegiatan Mahasiswa (UKM) seni tingkat universitas di Universitas Singaperbangsa Karawang (Unsika). Teater Gabung merupakan UKM yang berdiri sejak 11 Februari 2000 dengan pementasan pertamanya pada tanggal 26 Agustus 2000 yang berjudul "Rawa Gede 1947". Pementasan tersebut digarap dalam rangka memperingati hari ulang tahun kemerdekaan Republik Indonesia yang ke-55. Sutradara yang menggarap pementasan monolog "Racun Tembakau" ini bernama Rahmat Hidayat. Rahmat Hidayat juga merupakan anggota Teater Gabung sekaligus alumni Fakultas Teknik yang sudah beberapa kali menyutradarai pementasan yang digarap oleh Teater Gabung dan terbilang sukses. Pada garapannya kali ini yaitu monolog "Racun Tembakau", Rahmat Hidayat sukses membuat aktor juga pementasannya membawa dua piala kebanggaan dalam acara lomba Siliwangi Monologue Event (SME) yang diadakan di Universitas Siliwangi. Tidak hanya sebagai sutradara, Rahmat Hidayat juga sering kali menjadi aktor dalam pementasan drama garapan Teater Gabung.

Dalam pementasan monolog "Racun Tembakau" karya Anton Chekov ini hanya terdapat satu pemain atau aktor yang terlibat. Briliando Simarmata merupakan aktor satu-satunya dalam pementasan ini yang tentu saja berperan sebagai Ivan Situmorang. Briliando Simarmata merupakan anak kelahiran Batam pada 21 November 1998. Beliau juga merupakan mahasiswa Universitas Singaperbangsa Karawang yang tergabung dalam organisasi Teater Gabung. "Racun Tembakau" bukan pementasan perdana sejak terjun ke dunia teater. Briliando merupakan angkatan 2016 di Fakultas Ilmu Komputer di Unsika.

\section{Proses Penggarapan Pementasan Monolog "Racun Tembakau"}

Pementasan "Racun Tembakau" menjadi salah satu garapan monolog dari Teater Gabung. Dalam mementaskan sebuah pertunjukan, perlu dilakukan beberapa persiapan terlebih dahulu dengan tujuan agar menciptakan pementasan yang apik dan menarik serta tidak membosankan. Persiapan tersebut antara lain: pemahaman naskah yang dilakukan oleh sutradara, menyeleksi aktor yang nantinya dipilih langsung oleh sutradara, pembentukan tim artistik yang meliputi tata panggung, tata rias dan busana, tata lampu (lighting), dan tata musik. Setelah semua tim artistik dan aktor sudah terbentuk, kemudian diadakan proses reading naskah oleh semua tim. Dan yang terakhir, sutradara mewajibkan setiap elemen, mulai dari aktor sampai dengan tim artistik untuk mengikuti proses latihan sesuai dengan jadwal yang telah disepakati bersama. Proses latihan berlangsung sampai dengan pementasan monolog "Racun Tembakau" dipentaskan.

\section{Tanda yang Menunjukkan Adanya Budaya Matriarki yang Terkandung dalam Pementasan Monolog "Racun Tembakau"}

Dalam pementasan monolog "Racun Tembakau" yang dimainkan oleh Teater Gabung Unsika, tokoh Ivan Situmorang merupakan seorang pria yang sudah lanjut usia yang bekerja sebagai penceramah di berbagai seminar. Namun, status sosial Ivan dalam keluarga yang seharusnya menjadi kepala keluarga malah direnggut oleh sang istri yang justru memiliki kekuasaan yang lebih tinggi di atas Ivan yang notabene seorang laki-laki. Ivan, sebagai seorang laki-laki sering kali merasa tertindas oleh sikap otoriter istrinya. Hal itu dapat dibuktikan dengan cuplikan adegan berikut ini: 
3209 Budaya Matriarki dalam Pementasan Monolog "Racun Tembakau” Karya Anton Chekov oleh Teater Gabung Unsika (Kajian Semiotika Charles S. Pierce)-Intan Fajri Mulyaningsih, Uah Maspuroh, Sinta Rosalina

DOI: https://doi.org/10.31004/edukatif.v3i5.1257

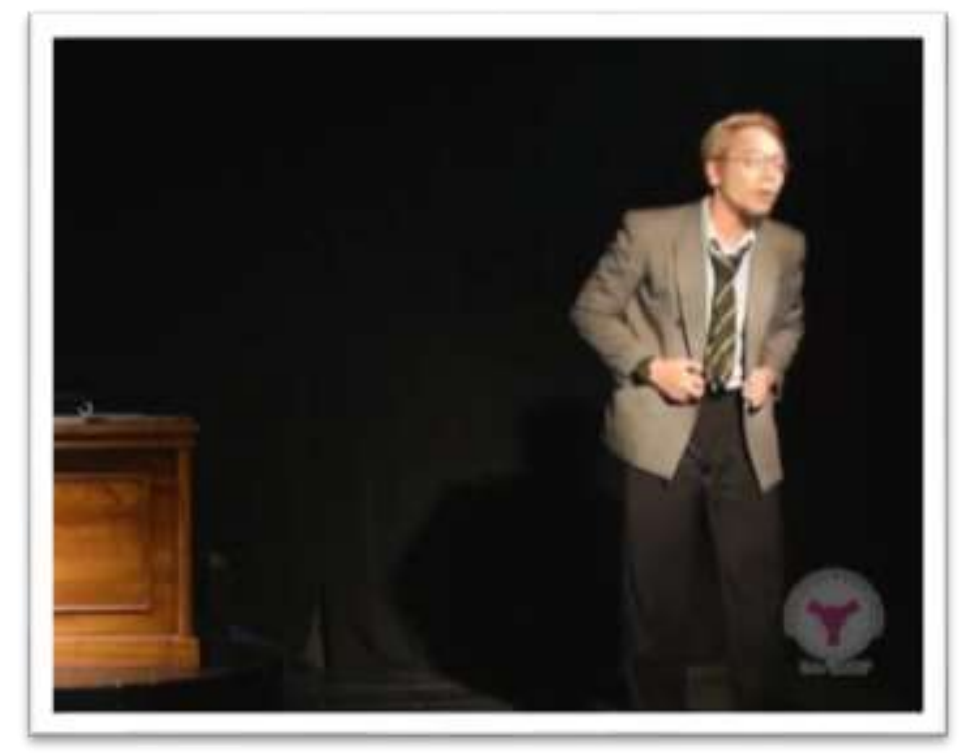

Gambar 1: Ketakutan Ivan

Dalam cuplikan adegan di atas, penonton diajak menyaksikan ketakutan yang dirasakan Ivan saat mengutarakan ujaran kebenciannya terhadap sang istri dalam sesi ceramahnya. Ivan khawatir jika istrinya tiba-tiba datang dan mendengar semuanya. Ditambah lagi dengan cupikan monolognya yang berbunyi, “...istri saya sudah ada di belakang panggung, sudah datang dan mengejar saya di sini. (Sembari melihat arlojinya) waktu sudah habis. Kalau ditanya istri saya, saya mohon, saya mohon dengan sangat, jawablah bahwa pemberi ceramahnya, bahwa si begeng, maksud saya, saya sendiri, telah melakukan tugasnya dengan sopan. (Menilik ke pinggir sembari batuk-batuk) istri saya sedang memandang saya...".

Budaya matriarki tentu terlihat jelas dalam pementasan monolog "Racun Tembakau" ini, hal tersebut digambarkan melalui sosok Ivan Situmorang yang takut dengan istrinya. Istri Ivan, yang notabene seorang perempuan sekaligus seorang ibu dalam keluarganya memegang kekuasaan yang mutlak atas keluarganya. Istri Ivan juga terlihat menjunjung tinggi kaum perempuan, terlihat dari usahanya mendirikan indekos yang dikhususkan bagi perempuan. Sedang Ivan seringkali ditugaskan untuk mengerjakan pekerjaan rumah tangga. Hal tersebut terlihat dari monolog Ivan, "saya turut mengatur indekos dengan menjaga urusan rumah tangga. Saya yang belanja persediaan makanan, saya awasi bujang-bujang, saya catat pengeluaran-pengeluaran dalam buku besar, saya lihat buku tulis anak-anak, saya pembasmi kutu-kutu, saya bawa jalan-jalan anjing kesayangan saya, saya nangkap tikus...".

Dengan adanya budaya matriarki yang sudah melekat dalam keluarga Ivan, menjadikan Ivan sering kali merasa terpaksa untuk patuh atau menuruti apa saja yang diperintahkan oleh sang istri. Sehingga mau tidak mau, Ivan yang merupakan seorang perokok berat harus menuruti perintah sang istri untuk memberikan ceramah tentang bahaya merokok dalam kegiatan seminar ilmiah. Namun saat seminarnya berlangsung, Ivan justru mengungkapkan bagaimana kebenciannya terhadap sang istri disertai rasa takut kalau saja isrinya mendengar tentang ceramahnya hari itu. Sontak saja, pada akhir pementasan ini Ivan bergegas kabur meninggalkan panggung setelah mendengar teriakan istrinya yang marah dari ujung ruangan. 
3210 Budaya Matriarki dalam Pementasan Monolog "Racun Tembakau” Karya Anton Chekov oleh Teater Gabung Unsika (Kajian Semiotika Charles S. Pierce)-Intan Fajri Mulyaningsih, Uah Maspuroh, Sinta Rosalina

DOI: https://doi.org/10.31004/edukatif.v3i5.1257

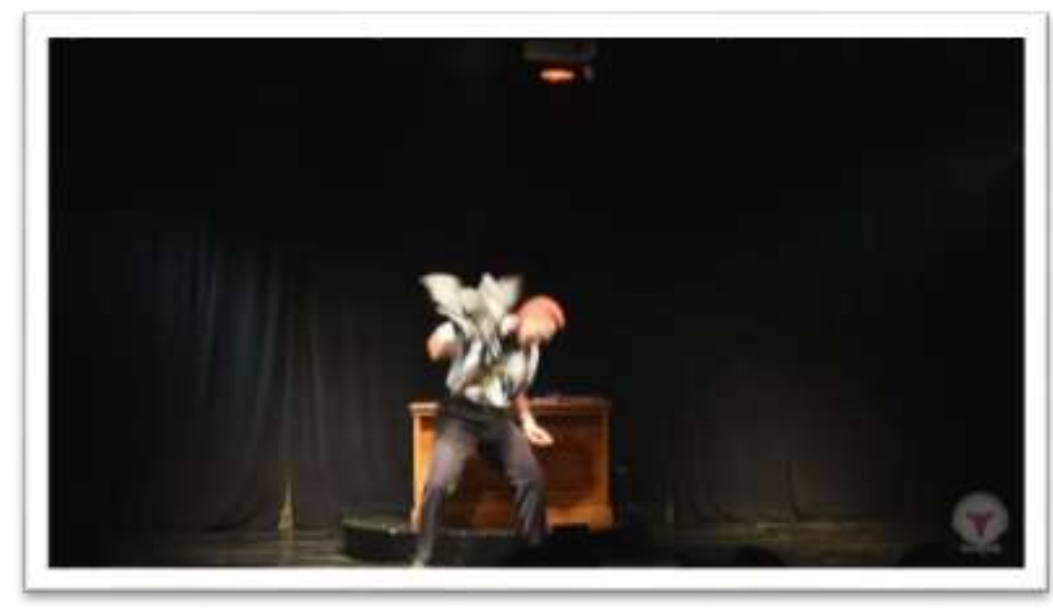

Gambar 2: Emosi Ivan

Cuplikan adegan di atas menunjukkan bahwa Ivan frustasi akan sikap otoriter dari sang istri. Dapat dilihat, bahwa Ivan sedang membuka jas tua yang telah dipakai selama 33 tahun sejak pernikahannya. Kemudian ia injak-injak jas itu sambil bermonolog. Begini bunya monolog Ivan, "rasain loh! Aku tua, melarat, sengsara, seperti jas tua ini, dengan punggungnya yang tambal-tambal, bobo nyeh-nyeh (sembari memperlihatkan punggung). Aku tidak mau apa-apa, aku lebih suka, dan lebih baik dan lebih bersih dari itu, aku pernah muda, aku pernah belajar di universitas, aku pernah bercita-cita, aku pernah menganggap diriku lelaki, sekarang aku tidak mau apa-apa! Tidak apa-apa selain istirahat!".

Ivan yang selalu merasa tertindas oleh sikap otoriter sang istri juga dapat dibuktikan melalui mimik wajah Ivan saat seminar. Mimik merupakan gerakan yang berada pada area wajah seperti mulut, dahi, alis, dan hidung yang menandakan emosi atau keadaan perasaan seseorang. Bentuk mimik yang ditunjukkan dalam pementasan monolog "Racun Tembakau" adalah sebagai berikut:

Tabel 1. Makna Mimik Wajah

\begin{tabular}{lll}
\hline No. & \multicolumn{1}{c}{ Bentuk Mimik } & \multicolumn{1}{c}{ Interpretasi Makna Tanda } \\
\hline 1. & Menaikkan alis & Ingin memberitahu sesuatu. \\
\hline 2. & Mata sedikit melotot & Menunjukkan rasa marah atau kebencian. \\
\hline 3. & Dahi sedikit mengkerut & Menunjukkan rasa kesal terhadap istrinya. \\
\hline
\end{tabular}

Dalam cuplikan adegan di atas, mimik wajah yang ditunjukkan sang aktor, Briliando, dalam memerankan Ivan dapat diinterpretasikan bahwa Ivan sedang berusaha membuka seminarnya dengan ceramah tentang bahayanya merokok. Namun, di sesi awal seminar, Ivan justru melenceng dari topik pembicaraan. Bukan membicarakan bahaya dari asap rokok, Ivan malah menceritakan bagaimana perlakuan semena-mena sang istri terhadapnya. Hal itu menyebabkan Ivan menjadi berapi-api ketika membicarakan istrinya.

Tabel 2. Makna Mimik Wajah

\begin{tabular}{lll}
\hline No. & \multicolumn{1}{c}{ Bentuk Mimik } & \multicolumn{1}{c}{ Interpretasi Makna Tanda } \\
\hline 1. & Menutup mata & $\begin{array}{l}\text { Sedang merasa takut atau khawatir kalau } \\
\text { saja istrinya mendengar ceramahnya. }\end{array}$ \\
\hline 2. & Memonyongkan bibir & $\begin{array}{l}\text { Sedang berusaha mempraktikkan diriya } \\
\text { yang sedang ngambek dicelotehi istri. }\end{array}$ \\
\hline 3. & Mengerutkan kedua alis & Memikirkan sesuatu yang bersifat serius. \\
\hline
\end{tabular}


3211 Budaya Matriarki dalam Pementasan Monolog “Racun Tembakau” Karya Anton Chekov oleh Teater Gabung Unsika (Kajian Semiotika Charles S. Pierce)-Intan Fajri Mulyaningsih, Uah Maspuroh, Sinta Rosalina

DOI: https://doi.org/10.31004/edukatif.v3i5.1257

Mimik wajah Ivan dalam cuplikan adegan di atas menunjukkan kekesalan Ivan terhadap sang istri yang menyuruhnya untuk mengisi ceramah tentang bahaya tembakau bagi kesehatan. Padahal, istrinya tahu bahwa Ivan merupakan salah seorang perokok berat. Tetapi, bagi Ivan tidak ada jalan lain selain mengikuti perintah dari sang istri.

Selain mimik wajah, gerak tubuh (gesture) Ivan di atas panggung juga dapat menjadi pertanda adanya budaya matriarki dalam keluarga Ivan. Gesture dalam pementasan drama adalah gerakan yang dihasilkan aktor pada area tubuh dari kepala hingga kaki. Gesture yang dimunculkan dalam pementasan monolog "Racun Tembakau" antara lain sebagai berikut:

Tabel 3. Makna Gerak Tubuh

\begin{tabular}{lll}
\hline No. & \multicolumn{1}{c}{ Bentuk Gesture } & \multicolumn{1}{c}{ Interpretasi Makna Tanda } \\
\hline 1. & Badan sedikit membukuk & Menunjukkan seseorang yang sudah tua. \\
\hline 2. & $\begin{array}{l}\text { Tangan kiri disimpan ke } \\
\text { belakang }\end{array}$ & $\begin{array}{l}\text { Menandakan seorang pria tua yang } \\
\text { berusaha berdiri tegap. }\end{array}$ \\
\hline 3. & Menggerakan tangan kanan & $\begin{array}{l}\text { Sedang menjelaskan sesuatu kepada orang } \\
\text { lain. }\end{array}$ \\
\hline
\end{tabular}

Gesture yang ditunjukkan Ivan dalam cuplikan adegan di atas dapat diinterpretasikan bahwa Ivan merupakan seorang pria tua dengan badan yang sudah tidak tegap lagi. Sedang gerakan tangan yang dilakukan Ivan dapat ditafsirkan bahwa Ivan, yang merupakan seorang perokok berat sedang berusaha menjelaskan ceramahnya tentang bahaya merokok karena perintah dari istrinya yang mau tidak mau harus dilakukan oleh Ivan, walaupun setelah itu pembicaraannya menyimpang. Hal itu dilakukan Ivan agar istrinya tidak memakimakinya terus menerus karena enggan mengikuti perintah istri.

Tabel 4. Makna Gerak Tubuh

\begin{tabular}{lll}
\hline No. & \multicolumn{1}{c}{ Bentuk Gesture } & \multicolumn{1}{c}{ Interpretasi Makna Tanda } \\
\hline $\begin{array}{l}\text { Membungkukkan tangan dan } \\
\text { kaki }\end{array}$ & Pertanda bahwa Ivan sudah lelah. \\
\hline 2. & Menundukkan kepala & $\begin{array}{l}\text { Menandakan penyesalan dan kepasrahan } \\
\text { seorang penceramah yang takut dengan } \\
\text { istri. }\end{array}$ \\
\hline 3. & $\begin{array}{l}\text { Mengangkat kedua tangan ke } \\
\text { arah kepala }\end{array}$ & $\begin{array}{l}\text { Menandakan bahwa Ivan frustasi akan } \\
\text { keadaan. }\end{array}$ \\
\hline
\end{tabular}

Gerakan tubuh yang dilakukan Ivan dalam cuplikan adegan di atas, menunjukkan bahwa Ivan sudah lelah dan frustasi dengan sikap otoriter sang istri. Di usia yang sudah tidak muda lagi, Ivan hanya ingin istirahat. Maksudnya, istirahat dari istrinya yang membuat Ivan seringkali merasa tertindas sebagai seorang laki-laki.

\section{Tabel 5. Makna Gerak Tubuh}

\begin{tabular}{lll}
\hline No. & \multicolumn{1}{c}{ Bentuk Gesture } & \multicolumn{1}{c}{ Interpretasi Makna Tanda } \\
\hline 1. & Memegang jas yang dipakai & $\begin{array}{l}\text { Menunjukkan bahwa Ivan sedang panik } \\
\text { atau grogi. }\end{array}$ \\
\hline 2. & $\begin{array}{l}\text { Mata dan kepala condong ke } \\
\text { depan }\end{array}$ & $\begin{array}{l}\text { Menandakan bahwa Ivan sedang mencari } \\
\text { seseorang di depannya. }\end{array}$ \\
\hline
\end{tabular}


3212 Budaya Matriarki dalam Pementasan Monolog “Racun Tembakau” Karya Anton Chekov oleh Teater Gabung Unsika (Kajian Semiotika Charles S. Pierce)-Intan Fajri Mulyaningsih, Uah Maspuroh, Sinta Rosalina

DOI: https://doi.org/10.31004/edukatif.v3i5.1257

Dalam cuplikan adegan di atas, gesture yang dilakukan Ivan menunjukkan bahwa ia sedang merasa takut dan khawatir kalau saja istrinya tba-tiba datang dan mendengar pembicaraannya dalam seminar tersebut. Ivan mengintip-intip ke pinggiran panggung sebagai bentuk kewaspadaannya terhadap kedatangan sang istri nanti. Ivan juga sudah berpesan kepada pendegar ceramahnya agar tidak membocorkan isi ceramahnya hari ini kepada istrinya. Hal itu dilakukan Ivan agar terhindar dari kemarahan sang istri yang membuatnya selalu merasa tidak ada harga dirinya sebagai seorang laki-laki.

Tabel 6. Makna Gerak Tubuh

\begin{tabular}{lll}
\hline No. & \multicolumn{1}{c}{ Bentuk Gesture } & \multicolumn{1}{c}{ Interpretasi Makna Tanda } \\
\hline 1. & Mendongakkan kepala & Sebagai tanda bahwa Ivan merasa lega. \\
\hline 2. & Merentangkan kedua tangan & $\begin{array}{l}\text { Sebagai tanda bahwa Ivan sudah merasa } \\
\text { bebas dari sang istri. }\end{array}$ \\
\hline
\end{tabular}

Dalam cuplikan adegan di atas, gesture yang dilakukan Ivan dapat diinterpretasikan sebagai rasa bersyukur Ivan karena bisa mengungkapkan isi hatinya yang terpendam selama 30 tahun lebih pernikahannya. Selama seminarnya berlangsung, Ivan merasa seperti sudah terbebas dari ikatan yang terjalin di antara ia dengan sang istri. Gerakan tubuh tersebut bermaksud ingin menunjukkan kepada penonton bahwa setidaknya selama seminar berlangsung ia bisa istirahat dari ocehan sang istri yang selalu memanggil dirinya dengan sebutan yang kasar.

\section{Orisinalitas Penelitian}

Ketika membuat sebuah karya, tentu seseorang harus memperhatikan orisinalitas dari karya yang akan dibuat atau diciptakannya, baik itu karya seni maupun karya ilmiah atau akademik. Orisinalitas sendiri dapat diartikan sebagai penentu kesuksesan hasil karya yang dibuat. Terlebih lagi dalam karya ilmiah yang bersifat akademik, pastinya seorang peneliti harus menunjukkan bahwa karya yang dibuatnya itu orisinal. Maka dari itu, dalam penelitian ini penulis mengambil tiga contoh penelitian terdahulu yang serupa yang dijelaskan pada tabel di bawah.

Tabel 7. Orisinalitas Karya

\begin{tabular}{|c|c|c|c|c|}
\hline No. & $\begin{array}{l}\text { Nama Peneliti, Judul, } \\
\text { dan Tahun Penelitian }\end{array}$ & Persamaan & Perbedaan & $\begin{array}{l}\text { Orisinalitas } \\
\text { Penelitian }\end{array}$ \\
\hline 1. & $\begin{array}{l}\text { Petrus Poerwadi dan } \\
\text { Misnawati, Kajian } \\
\text { Semiotik Pertunjukan } \\
\text { dalam Performa Drama } \\
\text { "Balada Sakit Jiwa }\end{array}$ & $\begin{array}{l}\text { Pada objek } \\
\text { penelitian }\end{array}$ & $\begin{array}{l}\text { Pada isi } \\
\text { kajiannya, yaitu } \\
\text { tentang } \\
\text { bagaimana tanda } \\
\text { yang diciptakan } \\
\text { untuk } \\
\text { menunjukkan } \\
\text { adanya budaya } \\
\text { matriarki dalam } \\
\text { pementasan } \\
\text { monolog "Racun } \\
\text { Tembakau". }\end{array}$ & $\begin{array}{l}\text { Kajian yang } \\
\text { diangkat, } \\
\text { mendeskripsikan } \\
\text { interpretasi yang } \\
\text { diperoleh dari } \\
\text { keseluruhan } \\
\text { makna yang } \\
\text { terdapat pada } \\
\text { objek penelitian } \\
\text { (pertunjukan } \\
\text { teater). }\end{array}$ \\
\hline 2. & $\begin{array}{l}\text { Zeldiana Hardyanthi } \\
\text { Putri dan Dra. Fahmi } \\
\text { Wahyuningsih, M.Pd., }\end{array}$ & $\begin{array}{l}\text { Pada } \\
\text { bidang } \\
\text { kajian }\end{array}$ & $\begin{array}{l}\text { Pada objek } \\
\text { penelitiannya, } \\
\text { materi, dan }\end{array}$ & $\begin{array}{l}\text { Kajian ini } \\
\text { menemukan } \\
\text { banyak tanda }\end{array}$ \\
\hline
\end{tabular}


3213 Budaya Matriarki dalam Pementasan Monolog “Racun Tembakau” Karya Anton Chekov oleh Teater Gabung Unsika (Kajian Semiotika Charles S. Pierce)-Intan Fajri Mulyaningsih, Uah Maspuroh, Sinta Rosalina

DOI: https://doi.org/10.31004/edukatif.v3i5.1257

\begin{tabular}{|c|c|c|c|c|}
\hline & $\begin{array}{l}\text { Analisis Semiotika } \\
\text { dalam Drama Der } \\
\text { Besuch Der Alten } \\
\text { Dame karya Friedrich } \\
\text { Durrenmatt. } 2015\end{array}$ & penelitian & $\begin{array}{l}\text { substansi } \\
\text { kajiannya yaitu } \\
\text { meneliti } \\
\text { pementasan } \\
\text { teater bukan } \\
\text { naskah } \\
\text { dramanya. }\end{array}$ & $\begin{array}{l}\text { dalam naskah } \\
\text { drama yang } \\
\text { kemudian } \\
\text { diklasifikasikan } \\
\text { menjadi } \\
\text { beberapa jenis } \\
\text { semiotika. }\end{array}$ \\
\hline 3. & $\begin{array}{l}\text { M. Hafi Ansori, } \\
\text { Analisis Semiotik } \\
\text { Pementasan Teater } \\
\text { Jauh di Sana ( } 2 \text { NU) } \\
\text { oleh Sanggar Latah } \\
\text { Tuah UIN Suska Riau. } \\
2018\end{array}$ & $\begin{array}{l}\text { Pada objek } \\
\text { penelitian }\end{array}$ & $\begin{array}{l}\text { Pada metode } \\
\text { penelitian dan isi } \\
\text { kajiannya } \\
\text { terfokus pada } \\
\text { budaya matriarki } \\
\text { dalam } \\
\text { pementasan } \\
\text { "Racun } \\
\text { Tembakau". }\end{array}$ & $\begin{array}{l}\text { Kajian ini } \\
\text { menunjukkan } \\
\text { bagaimana } \\
\text { pesan moral } \\
\text { yang ingin } \\
\text { disampaikan } \\
\text { sutradara dalam } \\
\text { pementasan. }\end{array}$ \\
\hline
\end{tabular}

Mengacu pada beberapa hasil penelitian di atas, ditemukan beberapa titik perbedaan yang sangat signifikan dengan penelitian ini, di antaranya yaitu: pertama, kajian difokuskan pada penelitian yakni ingin mengungkap bagaimana tanda-tanda dan simbol-simbol yang diciptakan oleh sutradara dan aktor untuk menunjukkan adanya budaya matriarki dalam pementasan monolog "Racun Tembakau", yang kedua yaitu penelitian ini hanya terbatas pada pembahasan semiotika dalam pementasan teater "Racun Tembakau".

\section{KESIMPULAN}

Semiotika merupakan ilmu yang membahas segala hal tentang tanda, sistem tanda, dan makna dari tanda itu sendiri. Ketika seseorang ingin menganilisis makna dan maksud dari suatu tanda, perlu digunakan kajian semiotika terhadap tanda tersebut. Seni teater dapat didefinisikan sebagai seni pertunjukan. Maksudnya, setiap hal yang dipertontonkan di atas panggung bisa disebut seni teater. Namun, tidak sedikit yang memahami bahwa seni teater hanya terpatok pada drama, yang mana drama merupakan seni bermain peran yang melibatkan aktor di dalamnya. Di dalam pertunjukan drama, seorang sutradara dan aktor menciptakan banyak tanda yang bisa menimbulkan banyak penafsiran dari masing-masing penonton. Maka dari itu, teori semiotika perlu digunakan untuk mengkaji makna dari tanda yang diciptakan dalam sebuah pertunjukan teater. Dengan berdasarkan pada teori semiotika Charles S. Pierce, dapat disimpulkan bahwa dalam pementasan monolog "Racun Tembakau" karya Anton Chekov yang dimainkan oleh Teater Gabung Unsika terdapat banyak tanda yang menunjukkan adanya budaya matriarki dalam keluarga Ivan Situmorang, tokoh dalam monolog tersebut.

\section{UCAPAN TERIMA KASIH}

Tidak lupa, penulis ucapkan terima kasih sebesar-besarnya, yang utama kepada Tuhan yang maha baik karena telah memberikan kelancaran selama proses penyusunan penelitian ini. Kedua, terima kasih diucapkan kepada kedua orangtua, karena atas dukungan dan do'a-nya penulis dapat menyelesaikan penelitian ini. Dan tentu saja penulis ucapkan terima kasih kepada portal jurnal Edukatif: Jurnal Ilmu Pendidikan karena telah menerima dan berkenan untuk mempublikasikan penelitian yang sekiranya masih banyak kekurangan ini. 
3214 Budaya Matriarki dalam Pementasan Monolog “Racun Tembakau” Karya Anton Chekov oleh Teater Gabung Unsika (Kajian Semiotika Charles S. Pierce)-Intan Fajri Mulyaningsih, Uah Maspuroh, Sinta Rosalina

DOI: https://doi.org/10.31004/edukatif.v3i5.1257

\section{DAFTAR PUSTAKA}

Abdul Latiff, A. B. (2006). Aplikasi Teori Semiotika Dalam Seni Pertunjukan. Etnomusikologi, 2(1), 45-51.

Adnyani, N. K. S. (2016). Bentuk Perkawinan Matriarki Pada Masyarakat Hindu Bali Ditinjau Dari Perspektif Hukum Adat Dan Kesetaraan Gender. Jurnal Ilmu Sosial Dan Humaniora, 5(1). Https://Doi.Org/10.23887/Jish-Undiksha.V5i1.8284

Aristia Putra, R., \& Abdillah, A. (2020). Peran Kenthongan Sebagai Penanda Pementasan Kethoprak Siswo Budoyo Di Kabupaten Tulungagung (Kajian Semiotika). Apron Jurnal Pemikiran Seni Pertunjukan, $1(15)$.

Hermawan, S. (2016). Tipologi Tanda Dalam Balamut Lakon Dan Pemaknaannya. Lentera: Jurnal Pendidikan, 11(2). Https://Doi.Org/10.33654/Jpl.V11i2.415

Hidayat, R. (2014). Analisis Semiotika Makna Motivasi Pada Lirik Lagu "Laskar Pelangi" Karya Nidji. Ejournal Ilmu Komunikasi, 2(1), 243-258. Http://Www.Fisip-Unmul.Ac.Id

Jiwa, B. S., Poerwadi, P., Bahasa, P., \& Keguruan, F. (N.D.). Kajian Semiotik Pertunjukan Dalam Performa Drama.

Lubis, A. A. (2021). Analisis Semiotika Charles Sanders Peirce Pada Sampul Majalah Tempo Edisi Satu Perkara Seribu Drama. Ikra-Ith Humaniora, 5(1), 184.

Moleong, L. J. (2007). Metodologi Penelitian Kualitatif. In Pt Remaja Rosdakarya: Vol. Edisi Revi.

Murniati, M., \& Arifin, Z. (2019). Pesan Komunikasi Non Verbal Dalam Sebuah Pementasan Teater (Study Analisis Semiotika Pada Pertunjukan Teater Sma Lb N Senenan Jepara). An-Nida: Jurnal Komunikasi Islam, 11(2). Https://Doi.Org/10.34001/An.V11i2.1029

Nugraha, R. P. (2016). Konstruksi Nilai-Nilai Nasionalisme Dalam Lirik Lagu (Analisis Semiotika Ferdinand De Saussure Pada Lirik Lagu "Bendera"). Jurnal Ilmu Ekonomi Dan Sosial, 5(3), 290-303. Https://Www.Neliti.Com/Id/Publications/237541/Konstruksi-Nilai-Nilai-Nasionalisme-Dalam-LirikLagu-Analisis-Semiotika-Ferdinan

Nurrachman, D. (2017). Teks Sastra Dalam Perspektif Semiotika Pragmatis Charles Sanders Peirce. AlTsaqafa: Jurnal Ilmiah Peradaban Islam, 14(1), 83-88. Https://Doi.Org/10.15575/AlTsaqafa.V14i1.1793

Ramli, A. (2021). Nilai-Nilai Budaya Makassar Dalam Karakter Tokoh Pertunjukan Teater The Eyes Of Marege. Nuansa Journal Of Arts And Design, 4(2), 47. Https://Doi.Org/10.26858/Njad.V4i2.19132

Sahid, N. (2016). Semiotika Untuk Teater, Tari, Wayang Purwa, Dan Film. In Tarling Sebagai Teater Daerah Indramayu Dalam Kajian Unsur-Unsur Penyajiannya (Issue 8). Http://Www.Jurnal.Uii.Ac.Id/Index.Php/Jee/Article/Viewfile/4418/3906

Sidik, A. (2018). Analisis Iklan Produk Shampoo Pantene Menggunakan Teori Semiotika Pierce. Technologia: Jurnal Ilmiah, 9(4), 201. Https://Doi.Org/10.31602/Tji.V9i4.1533

Supendi, E. (2007). Wayang Orang Sebagai Pertunjukan Teater Tradisional Dalam Tinjauan Semiotika. In Ilmu Dan Seni: Vol. Vol. 5 No. (P. 54).

Susanto, D. (2007). Matriarki Dan Hidden Women Dalam Syair Damarwulan. Atavisme, 10(2), 1-9. Https://Doi.Org/10.24257/Atavisme.V10i2.236.1-9

Widianto, R., Warouw, D. M. D., \& Senduk, J. J. (2015). Analisis Semiotika Pada Film Senyap Karya Joshua Oppenheime. Acta Diurna, 4(4), 1-9. 